\title{
Study of the Accuracy of Methane Concentration Forecasts in the Area of Longwall Outlet B-3 in Seam 407/1 in KWK "Borynia-Zofiówka" Ruch Zofiówka
}

\author{
Henryk Badura \\ Politechnika Śląska, Poland \\ Marian Zmarzły, Paweł Trzaskalik \\ KWK „Borynia-Zofiówka” Ruch Zofiówka, Poland \\ Aleksandr Ivanovich Korshunov \\ Federal Research Center of the Ural Branch \\ of the Russian Academy of Sciences, Russia
}

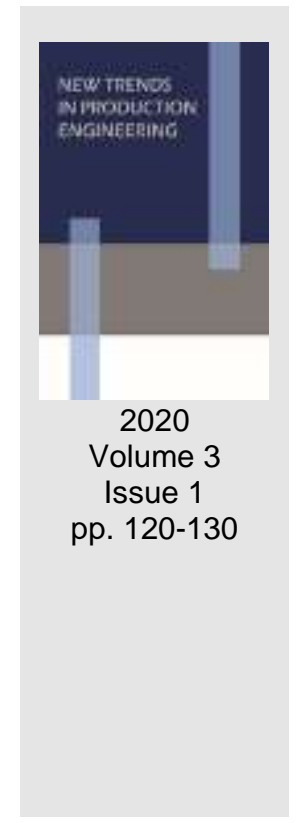

Date of submission to the Editor: 02/2020

Date of acceptance by the Editor: 03/2020

\section{INTRODUCTION}

Forecasts concerning the intensity of methane emission from the rock mass into the space of mine excavations, impact of the size of sections are very important in identification of methane hazard levels (Kozłowski B, 1972; Lunarzewski L. W., 1998; Krause E, Łukowicz K., 2000; Drzewiecki J., 2004; Borowski et al., 2009; Krause E., Wierzbiński K., 2009; Karacan et al., 2011; Krause E., 2015; Mishra D.P., 2018).

The state of methane explosion hazard is determined by the concentration and distribution of methane in the ventilation air as well as the possibility of explosion initials. The forecast of methane concentration in the mine atmosphere is important for maintaining a sufficiently high safety condition in mine excavations.

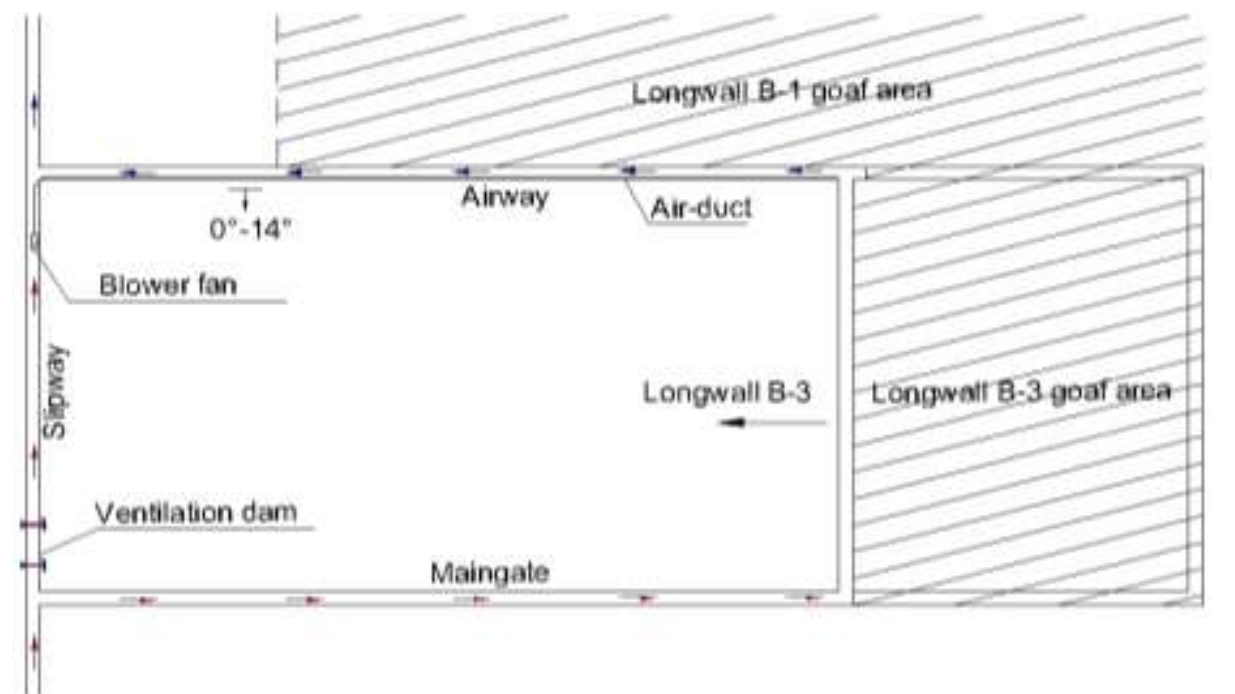

Fig. 1 Scheme of excavations in B-3 longwall area in seam 407/1 
The papers that address this issue are, e.g.: Badura H. (2004); Branny M. (2006); Badura H. (2007); Krause E. et al. (2008); Badura (2011), Badura H. (2013); Łukaszczyk Z., Badura H. (2018); Mishra D.P. (2018); Niewiadomski A., Badura H. (2019); Tutak M., Brodny J., (2018); Zmarzły M., Trzaskalik P. (2019). The paper presents research results of the relations between indications of methane concentration sensors at the airway outlet (CSM-5) and up to $10 \mathrm{~m}$ in front of the longwall face (CSM-4) and in the longwall, in the area of its outlet (CSM-1). The basis for calculations and considerations presented in the paper were measurements of methane concentration in the area of longwall B-3 in seam 407/1 in KWK "Borynia-Zofiówka" Ruch Zofiówka (Fig. 1 and Fig. 2).

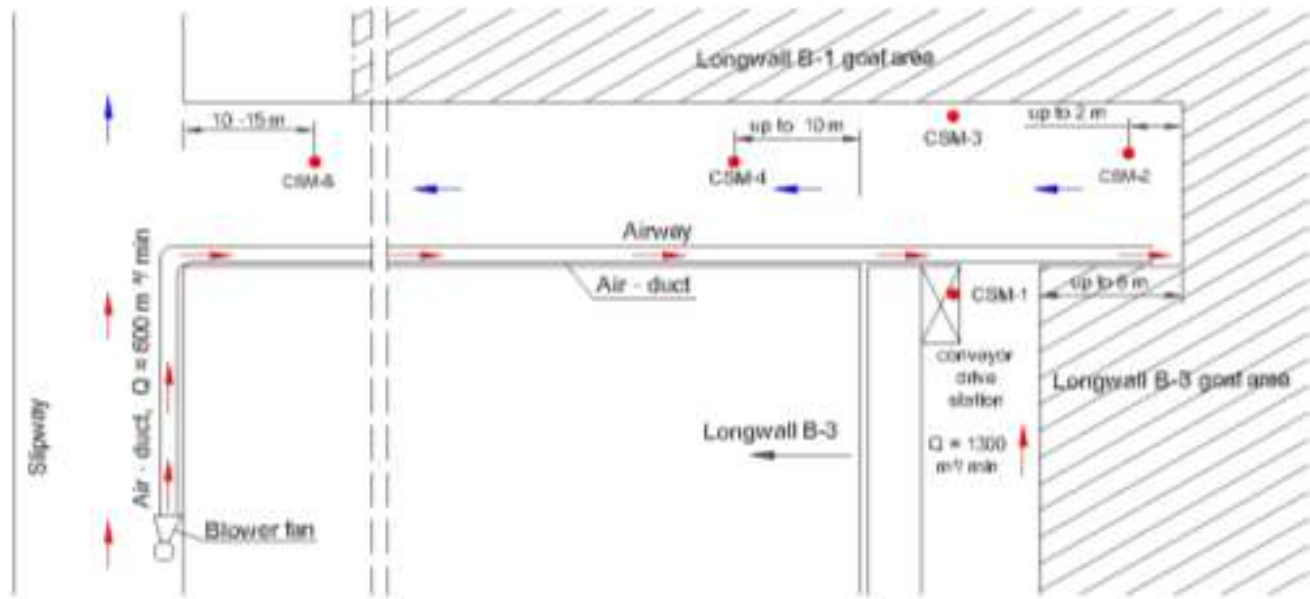

Fig. 2 Scheme of methane concentration sensors arrangement in B-3 longwall airway

\section{ANALYSIS OF MEASUREMENT DATA FOR METHANE CONCENTRATION}

Measurement data of average methane concentration in the locations of the above mentioned sensors form time series. Tests of normal distribution of mean methane concentration showed that none of the time series in question has a normal distribution.

Table 1 shows selected parameters characterizing these series.

Table 1 Selected parameters of time series for average methane concentration at the airway outlet (CSM-5) and up to $10 \mathrm{~m}$ in front of the longwall (CSM-4) and at the longwall outlet (CSM-1)

\begin{tabular}{|l|c|c|c|c|c|c|}
\hline Sensor & $\begin{array}{c}\text { Average } \\
\text { value }\end{array}$ & Median & $\begin{array}{c}\text { Minimum } \\
\text { value }\end{array}$ & $\begin{array}{c}\text { Maximum } \\
\text { value }\end{array}$ & $\begin{array}{c}\text { Percentile } \\
\mathbf{0 . 9}\end{array}$ & $\begin{array}{c}\text { Total } \\
\text { concentrations }\end{array}$ \\
\hline CSM-1 & 0.69 & 0.69 & 0.30 & 1.23 & 0.96 & 239.88 \\
\hline CSM-4 & 0.67 & 0.65 & 0.25 & 1.18 & 0.96 & 231.22 \\
\hline CSM-5 & 0.60 & 0.60 & 0.28 & 1.01 & 0.84 & 206.78 \\
\hline
\end{tabular}

The data in Table 1 show that the highest parameters of methane concentration have measurements of average methane concentration in the longwall, near its outlet, and the lowest in airway, at the outlet, i.e. near the intersection with a slipway. The reasons for the lower values of discussed parameters at the airway outlet compared to the values at a distance of up to $10 \mathrm{~m}$ in front of the longwall are better methane mixture with air and the diffusion phenomenon causing 
"leaching" of short-term increases in methane concentration that occur near the longwall outlet.

The coefficient of variation, i.e. the quotient of standard deviation to the average value of methane concentration, is also an important indicator characterizing methane concentration at the sensor locations. The values of this statistical parameter are: at the longwall outlet (CSM-1) - 28.4\%, up to $10 \mathrm{~m}$ in front of the longwall (CSM-4) - 21.7\%, at the airway outlet (CSM-5) - 23.3\%. Therefore, the coefficient of variation is also the highest for methane concentration at the longwall outlet.

In the discussed time series there is an autocorrelation. The autocorrelation coefficient of average methane concentration values at the airway outlet is $r=$ 0.84 , at a distance of up to $10 \mathrm{~m}$ in front of the longwall it is $r=0.84$ and at the longwall outlet it is $r=0.80$. Therefore, it can be concluded that the relation between average methane concentration on a given day and average methane concentration on the previous day is significant (Zeliaś, 2000).

There is also a correlation between the time series in question. Thus, the correlation coefficient between average methane concentration: at the airway outlet (CSM-5) and at the longwall outlet (CSM-1) is $r=0.89$, at the airway outlet (CSM-5) and up to $10 \mathrm{~m}$ in front of the longwall (CSM-4) is $r=0.94$, while at the longwall outlet (CSM-1) and up to $10 \mathrm{~m}$ in front of the longwall (CSM-4) is $r=$ 0.92 . Relations between average methane concentrations are shown in Figures 3,4 and 5 .

The figures show values of determination coefficient $\left(R^{2}\right)$ for the above relations. The closest relation is between average methane concentrations at the longwall outlet and up to $10 \mathrm{~m}$ in front of the longwall, even though $1900 \mathrm{~m}^{3} / \mathrm{min}$ airmethane mixture flows through the airway and $1300 \mathrm{~m}^{3} / \mathrm{min}$ through the longwall. It can be assumed that the air-methane mixture at this point is heterogeneous and the value of methane concentration at the sensor location in airway is determined mainly by the air stream coming out of the longwall.

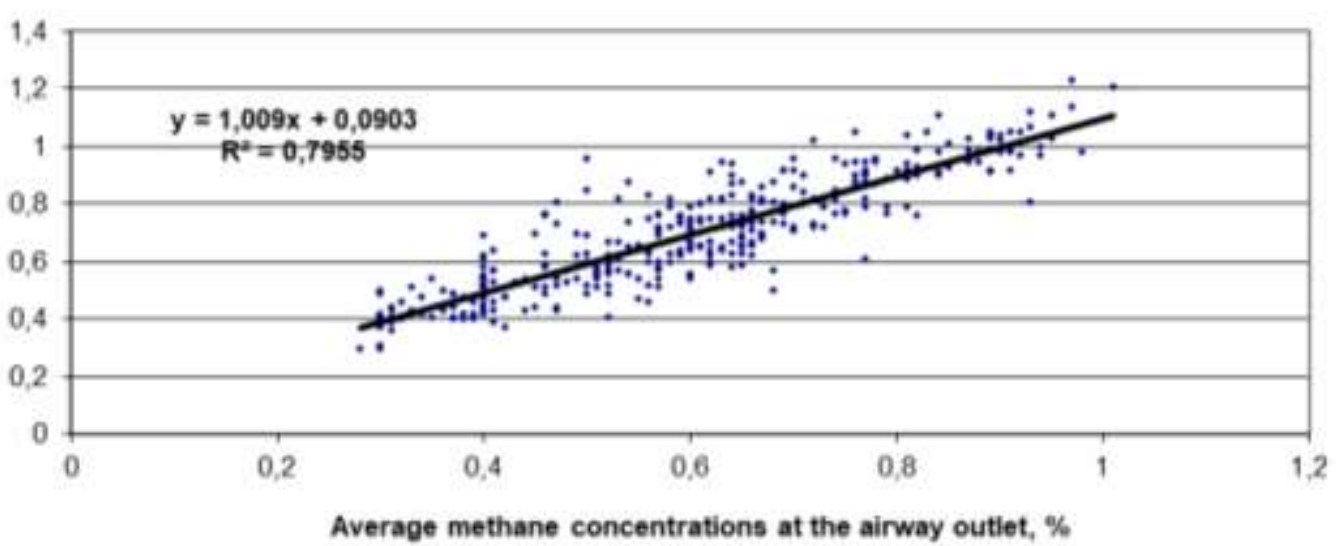

Fig. 3 Relation between average methane concentrations at the airway outlet and at the longwall outlet 


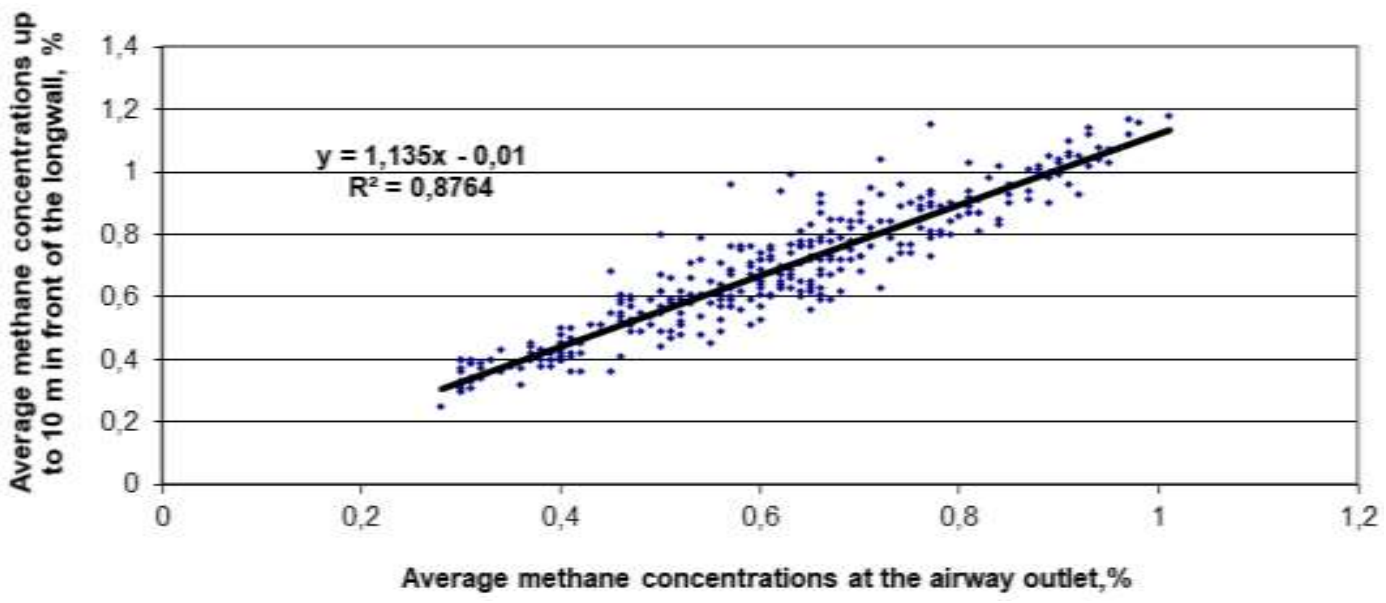

Fig. 4 Relation between average methane concentrations at the airway outlet and up to $10 \mathrm{~m}$ in front of the longwall

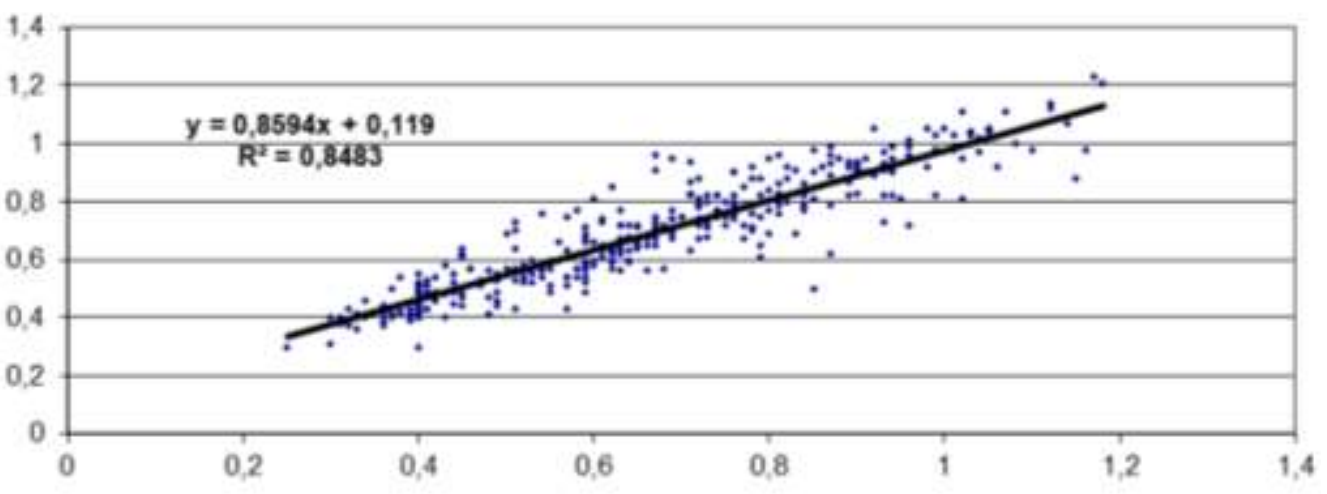

Average methane concentrations up to $10 \mathrm{~m}$ in front of the longwall, $\%$

Fig. 5 Relation between average methane concentrations up to $10 \mathrm{~m}$ in front of the longwall and at the longwall outlet

For forecasting reasons, it is interesting to note the correlation between average methane concentrations at the longwall outlet and up to $10 \mathrm{~m}$ in front of the longwall and methane concentration at the airway outlet on the previous day. They are $r=0.77$ and $r=0.80$, respectively. Therefore, they are lower than the autocorrelation factors.

For safety reasons, it may be important to forecast the methane concentration at the location of methane sensor, the indications of which include all sources of methane outflow in the longwall. Such a sensor is located up to $10 \mathrm{~m}$ in front of the longwall face (CMC-4). On the other hand, the most important is methane concentration at the longwall outlet (CSM-1) due to the possibility of initiating a methane explosion by a shearer near the longwall face.

In the presented paper an attempt was made to forecast the average methane concentration at the longwall outlet and in the airway at a distance of up to $10 \mathrm{~m}$ from the longwall face, using autocorrelation of average methane concentrations. 


\section{FORECASTS OF AVERAGE METHANE CONCENTRATION}

As there are no forecast equations that allow for forecasting methane concentration at the location of CSM-1 and CSM-4 sensors, the linear forecasting equations of methane concentration at the airway outlet (Badura $\mathrm{H}$. 2013) were used for this purpose with autocorrelation, the general form of which is presented in the equation:

$$
\mathrm{P}_{\mathrm{i}}=\mathrm{a}_{0}+\mathrm{a}_{1} \mathrm{~S}_{\text {pom }}-1
$$

where:

$a_{0}, a_{1}$ - parameters of the forecast equation,

$\mathrm{P}_{\mathrm{i}}$ - forecast methane concentration on i-th day,

Spom-1 - measured methane concentration on a day preceding i-th day.

The parameters of forecast equations, separate for each day of the week, were determined on the basis of measurements of average methane concentrations at the airway outlets of nine longwalls. In total, the measurements included indications of methane concentration in 2239 days (Badura H. 2013).

In order to assess the usefulness of these equations to forecast the average methane concentration at the longwall outlet and in the airway at a distance of up to $10 \mathrm{~m}$ in front of the longwall face, the forecasts of methane concentration at the airway outlet, i.e. in the place for which the forecast equations were developed, were also carried out. The errors of these forecasts were assessed and then compared with the errors of forecasts carried out for the locations of CSM-1 and CSM-4 sensors.

Measurement values and forecasted methane concentration at the airway outlet are shown in Figure 6, Figure 7 - up to $10 \mathrm{~m}$ in front of the longwall, and Figure $8-$ at the airway outlet.

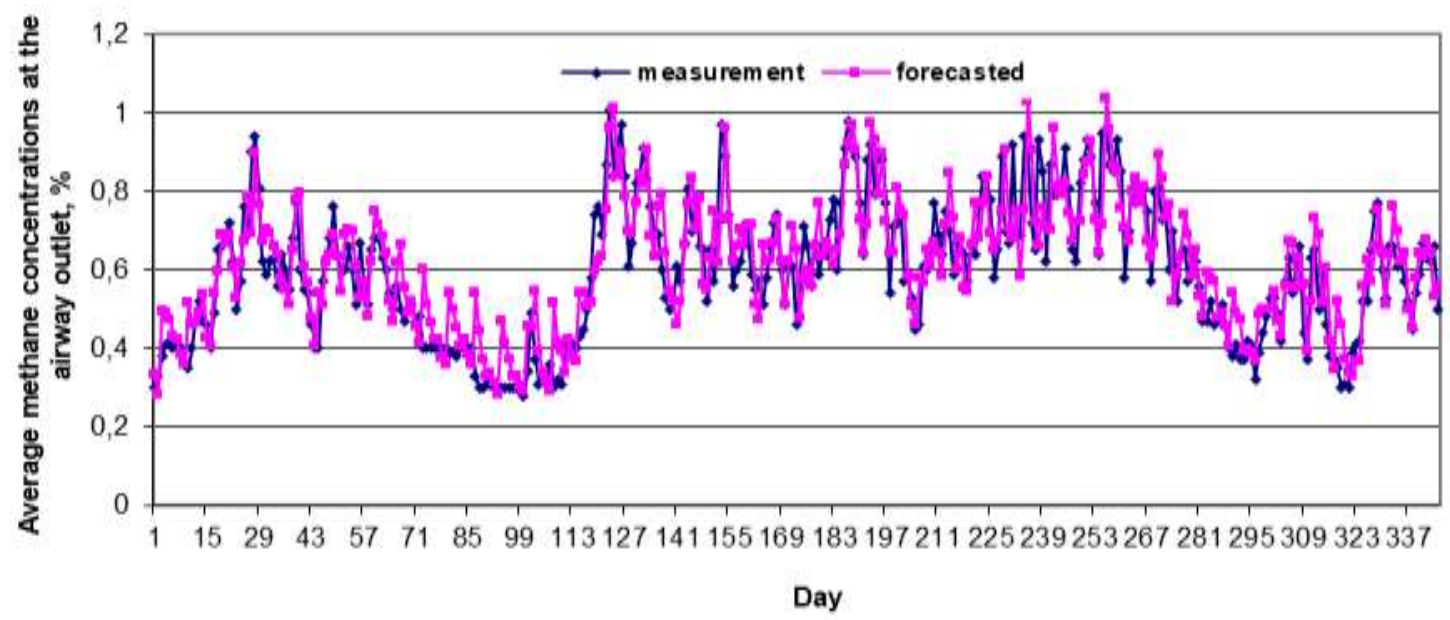

Fig. 6 Measurement and forecasted methane concentration at the airway outlet 


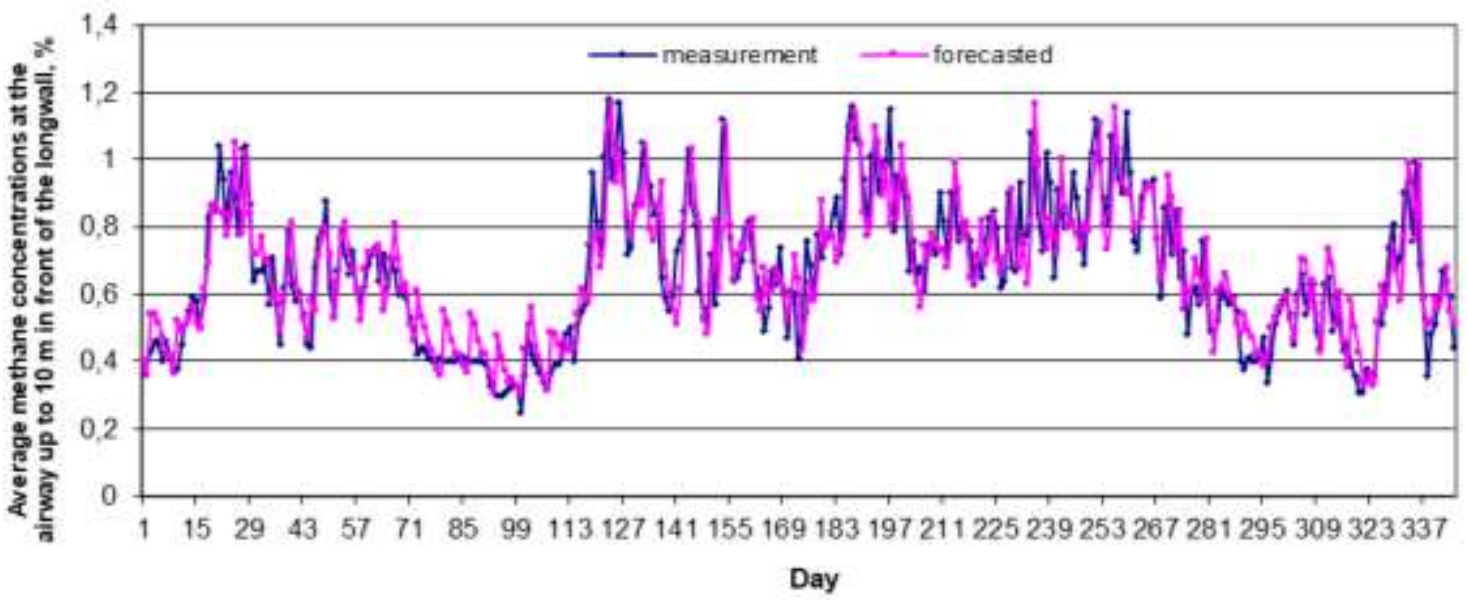

Fig. 7 Measurement and forecasted methane concentration at the airway up to $10 \mathrm{~m}$ in front of the longwall

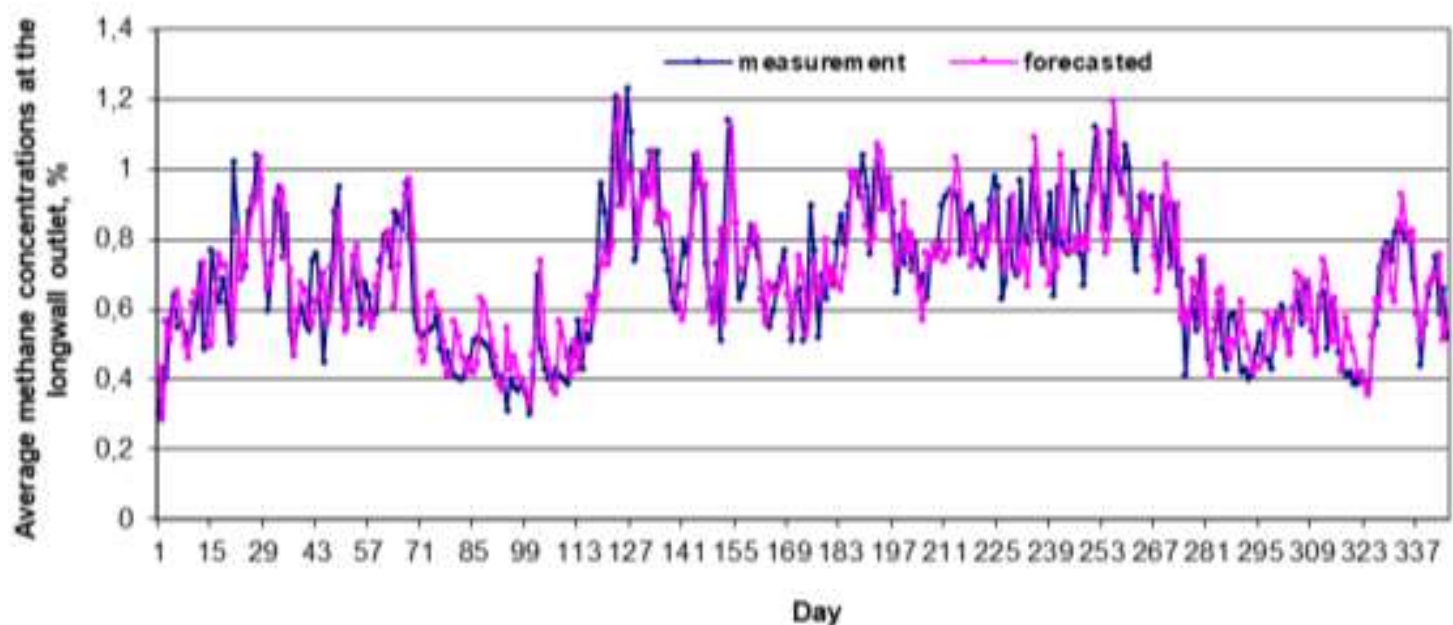

Fig. 8 Measurement and forecasted methane concentration at the longwall outlet

Figure 9 shows the number of absolute errors in the specified ranges of error values, and Figure 10 shows the percentage of absolute errors in the specified ranges.

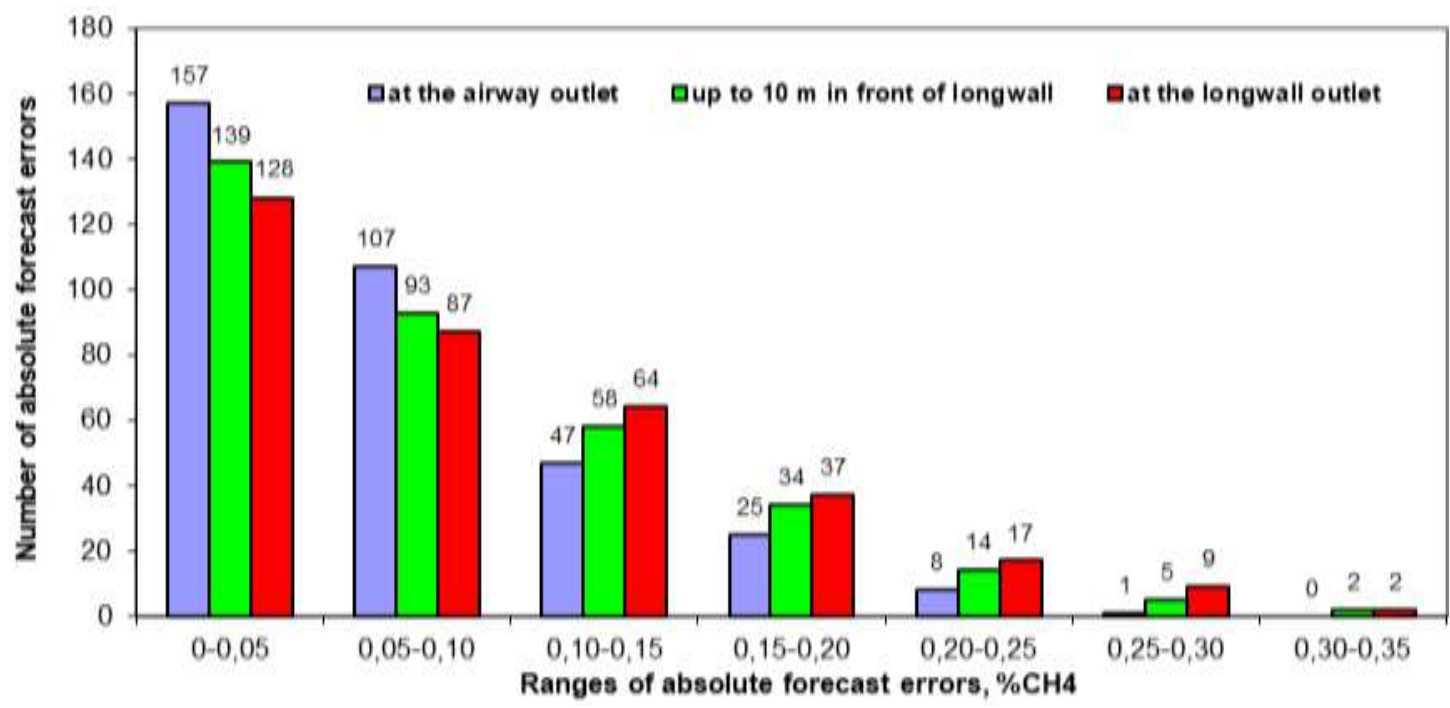

Fig. 9 Absolute errors in forecasting methane concentrations 


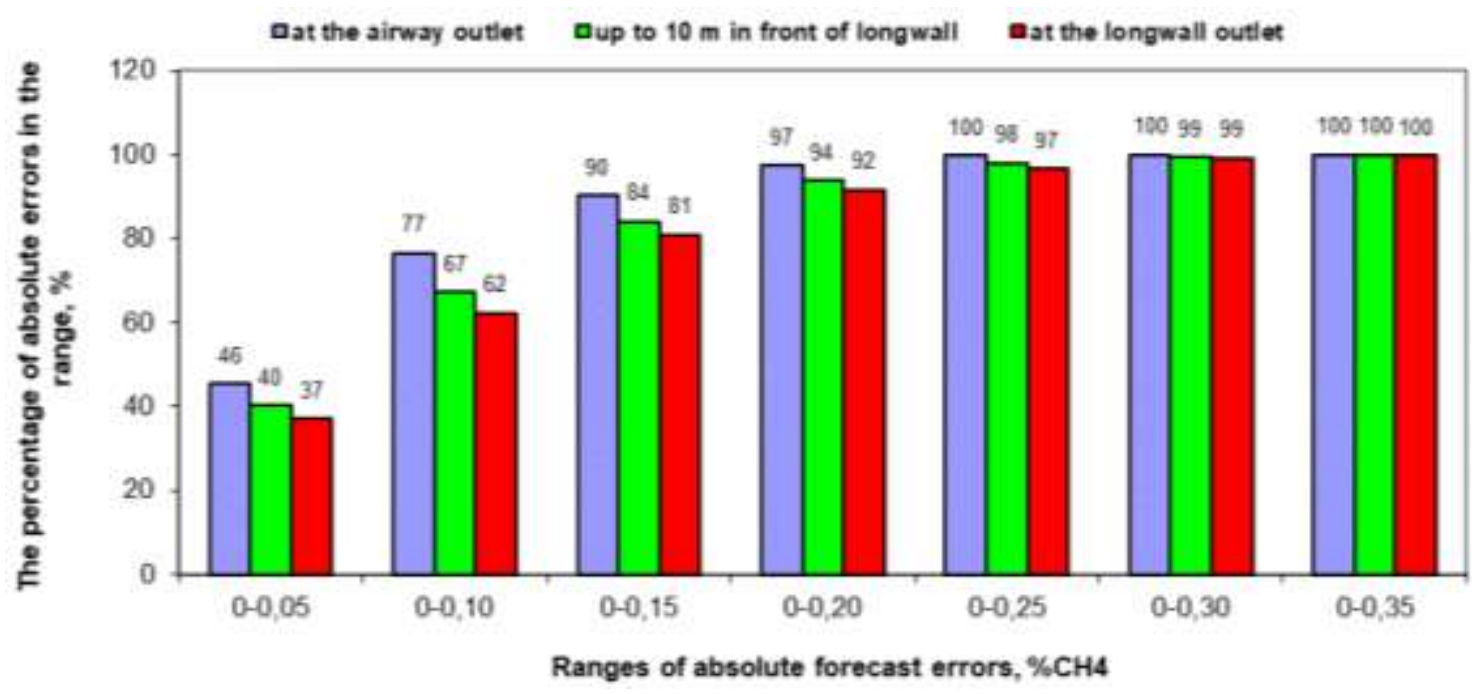

Fig. 10 Percentage of absolute errors in the increasing ranges of error values

In the further part of this publication, the forecast for airway outlet will be called the first forecast, the forecast for sensor location up to $10 \mathrm{~m}$ in front of the longwall - second forecast and the forecast for longwall outlet - third forecast. Figure 9 shows that for 157 first forecasts, absolute errors were no higher than $0.05 \% \mathrm{CH}_{4}$, which is $46 \%$ of all forecasts (Figure 10). The second forecast provided worse results, as the value of absolute errors no higher than $0.05 \% \mathrm{CH}_{4}$ was obtained for 139 forecasts (Figure 9), which constitutes $40 \%$ of all forecasts (Figure 10).

The least errors in the discussed range were reported by the third forecast. Their number is 128 , which constitutes $37 \%$ of all forecasts.

In the range from $0.05 \%$ to $0.10 \% \mathrm{CH}_{4}$ there are 107 absolute errors of the first forecast, 93 absolute errors of the second forecast and 87 errors of the third forecast (Fig. 9).

In the third range, $0.10-0.15 \mathrm{CH}_{4}$, the number of forecast errors of the first one is the smallest and is 47 , the number of forecast errors of the second one is 58 in this range and the number of forecast errors of the third one is 64 (Fig. 9). Therefore, in the discussed range of errors, the errors of third forecasts prevail, and the least errors concern the first forecast. This trend also applies to the further ranges of errors.

In the range $0-0.15 \% \mathrm{CH}_{4}$ there are already $90 \%$ of all absolute errors of the first forecast, $84 \%$ of the second forecast and $81 \%$ of the third forecast (Fig. 10).

The range of absolute errors $0.15-0.20 \% \mathrm{CH}_{4}$ includes 25 first forecast errors, 34 second forecast errors and 37 third forecast errors.

In the range $0-20 \% \mathrm{CH}_{4}$ there are $97 \%$ absolute errors in the first forecast, $94 \%$ in the second forecast and $92 \%$ in the third forecast.

A total of absolute forecast errors of the first one is $23.67 \% \mathrm{CH}_{4}$, the second one is $28.31 \% \mathrm{CH}_{4}$ and $30.97 \% \mathrm{CH}_{4}$.

As in the case of absolute errors, also the errors of the first forecast are the lowest. In the range $0-10 \%$, there are 187 relative forecast errors of the first, 170 forecast errors of the second and 157 forecast errors of the third (Fig. 11). 


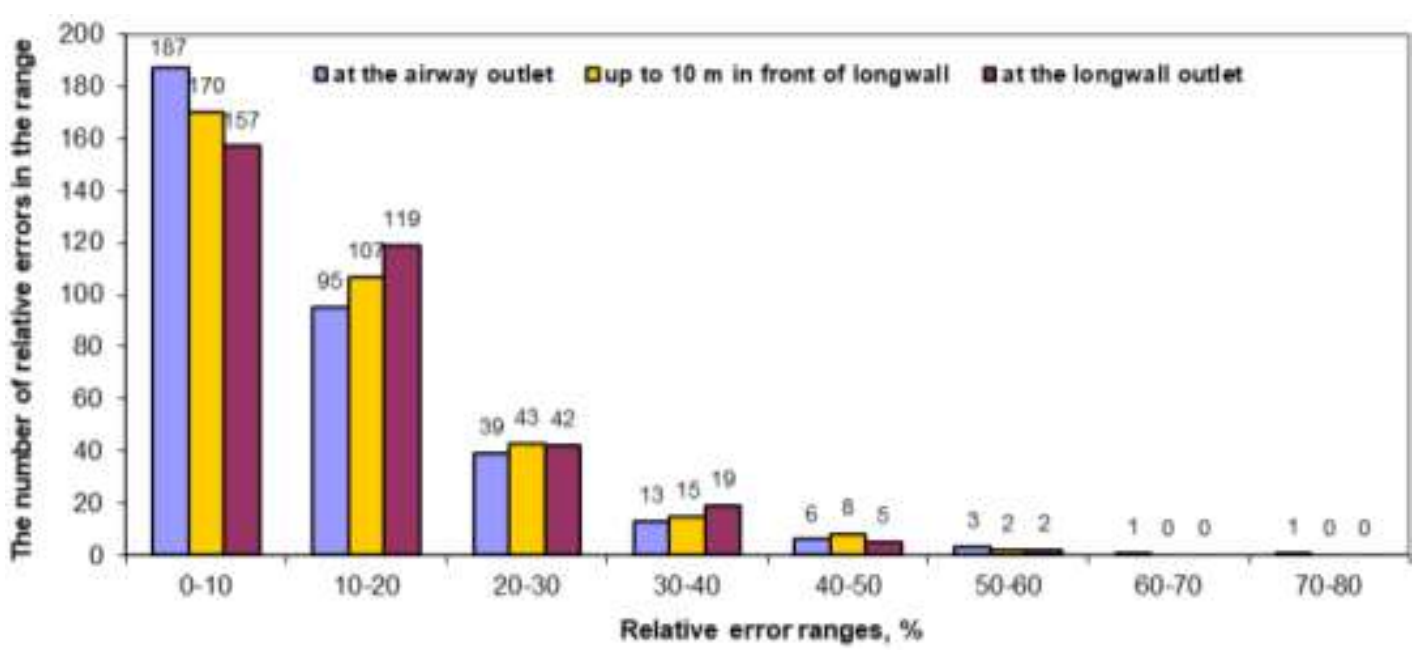

Fig. 11 Relative errors in forecasting average methane concentrations

In the second range of relative errors, which includes errors from $10 \%$ to $20 \%$, the highest number of errors, 119 errors, refers to the third forecast. The smallest number of 95 errors in the discussed range are relative errors of the first forecast, and 107 errors are forecast errors of the second. In the third range, from $20-30 \%$, the number of relative errors decreased drastically. The range includes 39 forecast errors of the first one, 43 forecast errors of the second and 42 forecast errors of the third.

Figure 12 shows that the range of relative errors from $0-10 \%$ includes $54 \%$ of the first forecast errors, $49 \%$ of the second forecast errors and $46 \%$ of the third forecast errors. The range of $0 \%-20 \%$ relative errors includes $82 \%$ of first forecast errors, $80 \%$ of second and third forecast errors.

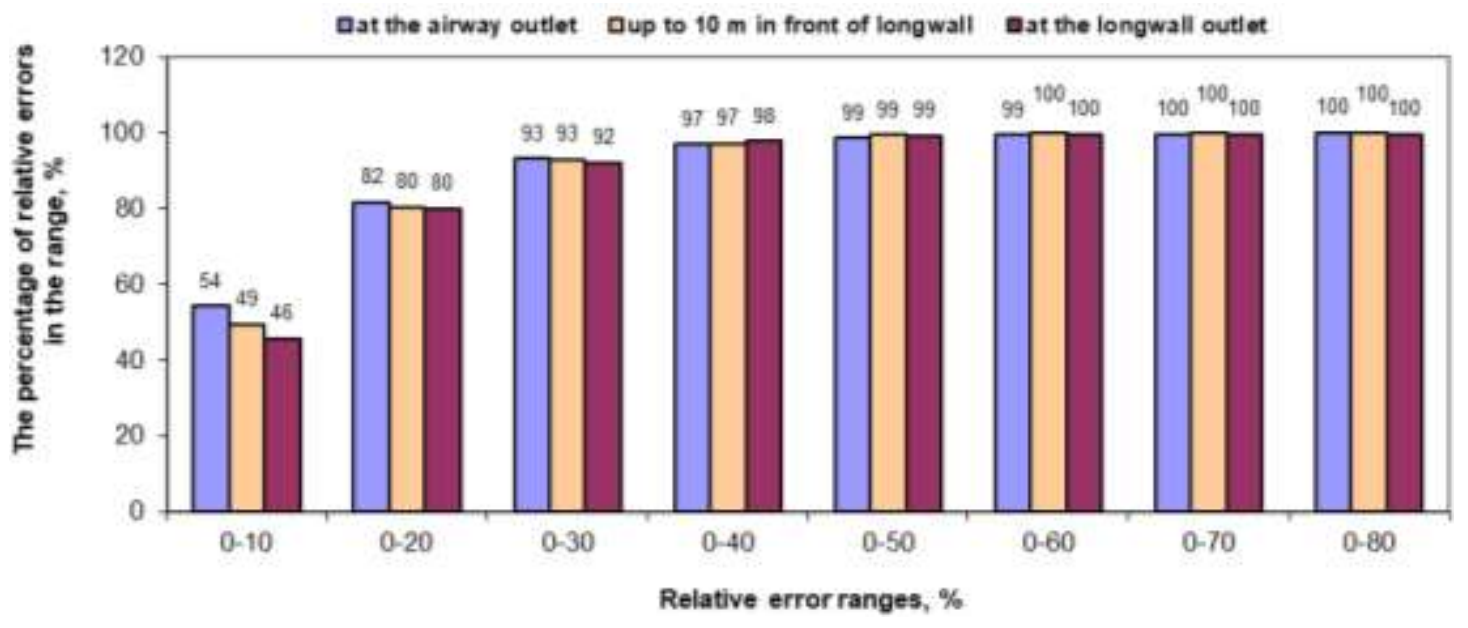

Fig. 12 Percentage of relative errors in the increasing ranges of error values

In the range of $0 \%-30 \%$ relative errors, $93 \%$ of first and second forecast errors and $92 \%$ of third forecast errors.

The error analysis shows that the forecast of methane concentration related to the location of methane concentration sensor up to $10 \mathrm{~m}$ in front of the longwall is more accurate than the forecast related to the longwall outlet. However, both forecasts are worse than the forecast of methane concentration at the airway 
outlet. However, as there are currently no forecast equations for methane concentration at these locations, the use of forecast equations for methane concentration at the airway outlet may be helpful in selection of preventive measures. The collection of suitably large measuring material and its analysis may lead to the development of forecast equations, adequate for the formation of methane concentration at the listed locations of the longwall area.

\section{CONCLUSION}

The forecasts used so far in the Polish mining industry refer to the absolute methane concentration of a longwall area or to the values of average methane concentration at the airway outlet.

This publication presents the possibility of making a one-day forecast of methane concentration at the sensor location in airway up to $10 \mathrm{~m}$ from a longwall. Methane concentration in ventilation air flowing out of the longwall and the part of airway located between longwall face line and airway decommissioning line has a significant impact on the methane hazard state in the immediate vicinity of longwall. Methane concentration at the longwall outlet is the most important measure of the methane explosion probability due to the highest possibility of explosion initiation from the excavating shearer.

The forecast of methane concentration in discussed locations may significantly influence the selection of preventive measures, in particular auxiliary ventilation measures in the area of longwall intersection with airway.

The research carried out in this publication has shown that in the analyzed case, the use of forecasting method based on forecast equations of methane concentration at the airway outlet gave good results of forecasting methane concentration in the airway, up to $10 \mathrm{~m}$ in front of the longwall, and slightly worse at the longwall outlet.

Obtained results encourage to further research in the scope addressed in this publication. The forecasted results are the formulation of adequate forecast equations for methane concentration at the longwall outlet and at a distance of up to $10 \mathrm{~m}$ in front of the longwall. Until the formulation of appropriate forecast equations and testing their accuracy, the forecasts presented in this publication may be helpful.

\section{REFERENCES}

Badura H., (2004). Simulación de la emission de metano en un tajo de carbon mediante un modelo matematico. Ingeopres, NOV, (132)

Badura H., (2007). Analiza stężeń metanu na wylocie z rejonu ściany P-4 w KWK "R". Górnictwo i Geologia. Kwartalnik, vol. 2, pp. 5-16, Gliwice, Poland

Badura H., (2011). Wykorzystanie uogólnionej metody najmniejszych kwadratów Aitkena do estymacji parametrów modelu metanowości rejonu ściany. Asociace Technickych Diagnostiku Ceske Republiky o.s. Technicka Diagnostika, z1, rocznik XX.

Badura H., (2013). Short-Term Methods for Methane Concentrations at The Outlets from Caving Longwall Areas at Coal Mines. Monograph. Silesian University of Technology Press. Gliwice, Poland 
Borowski M., Szlązak N., Obracaj D., (2009). Methane hazard predictions in underground coal mining. Conference: Deep mining challenges. International Mining Forum 2009, At 18-21 February, Kraków

Branny M., (2006). Computer Simulationof Flow of Aer and Methane mixture in The Longwall-Return Crossing Zone. Arch. Mining Science Vol. 51, pp. 133-145

Drzewiecki J., (2004). Metanowość ścian a postęp eksploatacyjny. Arch. Min. Sci., Vol. 49.

Jura B., Skiba J., Wierzbiński K. 2014. Applicability of surface directional wells for upper Silesia Basin coal seams' drainage ahead of mining. International Journal of Mining Science and Technology 24(3), pp. 353-362. https://doi.org/10.1016/j.jmst.2014.03.0124

Karacan, C.Ö.; Ruiz, F.A.; Cotè, M.; Phipps, S. (2011). Coal mine methane: A review of capture and utilization practices with benefits to mining safety and to greenhouse gas reduction. Int. J. Coal Geol. 86, pp. 121-156.

Krause E., Łukowicz K., (2004). Dynamiczna prognoza metanowości bezwzględnej ścian (poradnik techniczny) [Dynamic prediction of absolute methane emissions on longwalls (technical guide)]. Instrukcja nr 14 Główny Instytut Górnictwa, Katowice

Krause E., Cybulski K., Wierzbiński K., (2008). Modelowanie rozkładu koncentracji metanu w rejonie skrzyżowania chodnika wentylacyjnego ze ścianą. XXI Światowy Kongres Górniczy. Kraków-Katowice 7-11-pażdziernika.

Krause, E.; Wierzbiński, K. (2009). Wpływ przekrojów wyrobisk oraz uwarunkowań wentylacyjno-metanowych w środowisku ścian na kształtowanie się zagrożenia metanowego. Przegląd Górniczy, t. 65, pp. 52-60.

Krause E. (2015). Short-Term Predictions of Methane Emissions During Longwall Mining. Arch. Min. Sci., Vol. 60, No 2, pp. 581-594

Kozłowski B., (1972). Prognozowanie zagrożenia metanowego w kopalniach węgla kamiennego. Katowice, Wyd. „Śląsk”.

Lunarzewski L.W. (1998). Gas emission prediction and recovery in underground coal mines. International Jurnal of Coal Geology, vol. 35, pp. 117-145.

Łukaszczyk Z., Badura H., (2018). Comparison of Forecasts for Average Methane Concentration at Longwalls Using Autoregressive and Cause_Effect Models Using Daily Mining as Descriptive, Based on Data from The "Krupiński" Mine. www.ijera.com. ISSN; 2248-9622, vol. 8, Issue 10 (Part - V) Oct 2018, pp 70-80

Mishra, D.P.; Kumar, P.; Panigrahi, D.C. (2016). Dispersion of methane in tailgate of a retreating longwall mine: A computational fluid dynamics study. Environ. Earth Sci. 75, 475.

Mishra D., Panigrahi D., Kumar P. (2018). Computational investigation on effects of geo-mining parameters on layering and dispersion of methane in underground coal mines - A case study of Moonidih Colliery. Journal of Natural Gas Science and Engineering 53, pp. 110-124

Niewiadomski A., Badura H. (2019). Evaluation of one day average methane concentrations forecast at outlet from the longwall ventilation region as tool of supporting selection of methane prevention measures. Topical issues of rational use of natural resources 2019. Proceedings oft he XV International Forum Contest of Students and Yung Researchers under the auspices of UNESCO, St Petersburg, Russia, 13-17 May 2019. Vol.1, Ed. By Vladimir Litvinenko. London \& Francis Group, 2019, pp. 88-99

Rozporządzenie Ministra Energii z dnia 23 listopada 2016 r. w sprawie szczegółowych wymagań prowadzenia ruchu podziemnych zakładów górniczych. Dziennik Ustaw RP poz. 1118. Warszawa 09.06.2017

Szlązak N., Obracaj D., Swolkień J. (2014). Methane Drainage from Roof Strata Using and Overlying Drainage Galery. International Journal of Coal Geology, 136, pp. 99-115 
Tutak M., Brodny J., (2018). Analysis of the Impact of Auxiliary Ventilation Equipment on the Distribution and Concentration of Methane in the Tailgate. Energies, 11(11), 3076; https://doi.org/10.3390/en11113076 - 08 Nov 2018

Zeliaś A. (1997). Teoria prognozy. Polskie Towarzystwo Ekonomiczne, Warszawa.

Zmarzły M., Trzaskalik P. (2019). Comparative analysis of methane concentration near the junction of the longwall and top road. Management Sytems in Production Engineering. Vol. 27, issue 3, pp. 166-173

\begin{abstract}
.
In the presented publication, an ex post forecast of methane concentration at the airway outlet was carried out on the basis of equations previously developed and repeatedly tested by $\mathrm{H}$. Badura and its errors were calculated. This forecast was considered as a reference level. Next, using the same forecast equations, the forecasting of methane concentration at the sensor location up to $10 \mathrm{~m}$ in front of the longwall face and at the longwall outlet was carried out, followed by the analysis of forecast errors. Since the measurement of methane concentrations in the locations under consideration differed, the results of forecasts also differed. Therefore, in order to assess the accuracy of forecasts, their absolute and relative errors were calculated and then compared with the forecast errors at the airway outlet. The analysis of errors showed that there are differences in forecast accuracy and it is advisable to develop new forecast equations mainly for the longwall outlet, but also for the location of methane concentration sensor installed in the airway up to $10 \mathrm{~m}$ in front of the longwall.
\end{abstract}

Keywords: longwalls, methane hazard, methane concentration forecasts, testing of forecast accuracy 